\title{
Sweet dreams (are made of cellulose): Sociotechnical imaginaries of second-generation bioenergy in the global debate
}

\author{
Magdalena Kuchler
}

Linköping University Post Print

Tweet

N.B.: When citing this work, cite the original article.

Original Publication:

Magdalena Kuchler, Sweet dreams (are made of cellulose): Sociotechnical imaginaries of second-generation bioenergy in the global debate, 2014, Ecological Economics, (107), 431437.

http://dx.doi.org/10.1016/j.ecolecon.2014.09.014

Copyright: Elsevier

http://www.elsevier.com/

Postprint available at: Linköping University Electronic Press

http://urn.kb.se/resolve?urn=urn:nbn:se:liu:diva-110910 
TITLE

Sweet dreams (are made of cellulose): sociotechnical imaginaries of second-generation bioenergy in the global debate

\section{AUTHOR}

Magdalena Kuchler ${ }^{\mathrm{a}, \mathrm{b}}$

${ }^{\text {a } C e n t r e ~ f o r ~ C l i m a t e ~ S c i e n c e ~ a n d ~ P o l i c y ~ R e s e a r c h, ~ L i n k o ̈ p i n g ~ U n i v e r s i t y, ~ 60174, ~ N o r r k o ̈ p i n g, ~}$ Sweden

${ }^{\mathrm{b}}$ Department of Thematic Studies - Water and Environmental Studies, Linköping University, 58183, Linköping, Sweden

Email: magdalena.kuchler@liu.se

Phone: +46 13282285

\section{CORRESPONDING AUTHOR}

Magdalena Kuchler ${ }^{\mathrm{a}, \mathrm{b}}$

${ }^{\text {a }}$ Centre for Climate Science and Policy Research, Linköping University, 60174, Norrköping, Sweden

${ }^{\mathrm{b}}$ Department of Thematic Studies - Water and Environmental Studies, Linköping University, 58183, Linköping, Sweden

Email: magdalena.kuchler@liu.se

Phone: +46 13282285 


\section{ABSTRACT}

This paper critically examines the sociotechnical imaginaries of second-generation bioenergy technology in the global debate, exemplified by the deliberations of international organizations specializing in food and agriculture, energy security, and climate change. The analysis is guided by two objectives: first, to identify and illuminate visions of future advanced biofuels by implementing the concept of sociotechnical imaginaries; second, to scrutinize these imaginaries using a critical and diagnostic utopian method to determine whether the projected visions entail the promise of radical change and hope for socioeconomic transition to a "green" future, or instead manifest an ideological stranglehold striving to perpetuate the status quo. The article demonstrates that sociotechnical imaginaries of advanced biofuel technology superficially project the illusion of utopian potential. On closer examination, however, visions of future second-generation biofuels are limited by the necessity of cost-effectiveness that underpins market competitiveness. They manifest utopian impotence to imagine future beyond the ideological closure of the currently dominant socioeconomic system.

\section{KEYWORDS}

bioenergy, second-generation, sociotechnical imaginaries, international organizations, future, utopia

\section{Introduction}

The last three decades have seen intense scholarly, expert, and policy debate on the potentials of and obstacles to bioenergy production in global efforts to transition to a low-carbon economy. These often contentious deliberations have resonated in a much wider discussion of 
reimagining and reconfiguring the current global socioeconomic configuration into a more socially equitable and sustainable world (Bradshaw, 2013; Smith, 2010).

This discussion has focused largely on first-generation - i.e., traditional or conventional bioenergy in the form of ethanol and biodiesel processed from edible crops. First-generation, conventional biofuels processed primarily from sugar, starch, and oilseed crops represent a production pattern existing since the late nineteenth century (Worldwatch Institute, 2007). With the rapid rise of the automotive industry in the early twentieth century, biomass-derived energy briefly rose to prominence, being labelled the "fuel of the future", but the discovery of large reserves of abundant and cheap oil eventually marginalized the role of biofuels (Bernton et al., 2010). International interest in energy production from biomass was later revived twice: during the 1970s oil crisis and in the recent boom starting at the end of the twentieth century. In both instances, the resurgence of first-generation biofuels as an important alternative source of energy was triggered primarily by a sharp rise in oil prices (Bernton et al., 2010). However, apart from energy security concerns, two more major factors contributed to the latest biofuel rush, namely, agricultural stagnation and climate change. Simultaneously, the rapid increase of interest in first-generation bioenergy, particularly in developed countries, has prompted intense debates on how the growing production of biomass for fuel could affect world food security and land use (Kuchler and Linnér, 2012; Popp et al., 2012; Runge and Senauer, 2007), environmental protection (Pimentel, 2012; Smith, 2010), and trade relationships between the global North and South (Kuchler, 2010; Matondi et al., 2011).

In the shadow of this controversial and polarized debate on conventional bioenergy production, second-generation technology has attracted increasing attention in expert and policy-decision circles, as it is considered a more efficient and less problematic alternative solution to the global problems of energy insecurity, agricultural stagnation, and climate change. Second-generation, advanced biofuels can be produced from cellulosic feedstocks - 
wood, tall grasses, forestry and crop residues, and other organic wastes - using two currently available processes: enzymatic conversion and gasification (Worldwatch Institute, 2007).

However, advanced bioenergy is still immature and claimed to be "waiting around the corner" for the industry to kick start it, making it commercially available on a large scale. Following the World Energy Outlook 2011 of the International Energy Agency (IEA, 2011c), the latest final draft report of the Intergovernmental Panel on Climate Change (IPCC, 2014) notes that "advanced biofuels are in development, but may need another decade or more to achieve widespread commercial use" (p. 21). As such, second-generation biomass energy depends on future innovation and technological progress.

As Alf Hornborg (2014a) points out, though "a successful technical experiment does not provide sufficient evidence that a new technological system is 'feasible' or 'within reach", nevertheless, "such conclusions are very frequently drawn in both academic and public debates" (p. 12). Based on examination of the global discussion epitomized in reports and other expert documents issued by three major international organizations (IOs) in the 19902013 period, the overall objective of this paper is to chart and scrutinize sociotechnical imaginaries of second-generation biofuels by questioning whether the envisaged promise of change for a better "green" future through technological development is a symptom of the utopian impulse to provide a radical alternative, or instead manifests the ideological stranglehold that strives to perpetuate the dominant socioeconomic structure, and is therefore devoid of utopian potential.

More specifically, the analysis has two aims. First, by drawing on the concept of “sociotechnical imaginaries" introduced by Jasanoff and Kim (2009, 2013), I seek to identify and illuminate visions of future second-generation bioenergy in the global debate. The first objective is guided by questions regarding how advanced biofuel technology is imagined, the 
prescribed futures associated with the examined visions, and the premises on which these futures are based in reports and other expert documents issued by selected IOs.

Second, I scrutinize the utopian potential of these advanced biofuel imaginaries by employing the concept of "utopia" as a reflexive, critical, and diagnostic method as postulated by Fredric Jameson (1994, 2004, 2005, 2010) and Ruth Levitas (2000, 2003, 2007, 2011, 2013). The second objective is to identify differences and retrieve signals of otherness by determining how "green" and innovative the proposed future visions of advanced bioenergy technology are and how radical a transition they indeed promise (Jameson, 1994; Levitas, 2011). More specifically, I concentrate on three aspects of deliberations pursued by selected IOs: the premises on which the new and innovative character of second-generation biofuels is based and construed; the boundaries - beyond which the organizations do not go in their conceptualizations - drawn in these future imaginaries; the purpose of envisioning advanced bioenergy technologies as new and innovative and whether the purportedly better and greener impulse that could bring radical change is only illusory.

The analysis centres on the global biofuel debate in the 1990-2013 period as exemplified by three distinct but interrelated major IOs: the United Nations Food and Agriculture Organization (FAO), International Energy Agency (IEA), and Intergovernmental Panel on Climate Change (IPCC). Serving both developed and developing countries, the primary role of FAO is to lead international efforts to achieve global food security. This specialized body of the United Nations serves as a neutral platform for negotiating and debating agricultural policies and arguments. Set up in response to the 1970s oil crisis, IEA represents the collective response of a group of high-income countries to energy challenges and aspirations for energy security. The agency focuses on coordinating the implementation of energy cooperation between members through promoting energy efficiency and diversification. IPCC is an intergovernmental scientific body that leads in assessing knowledge of and information 
on climate change. Open to all member states of the United Nations, the Panel plays a prominent role in supplying decision makers with expertise on the environmental and socioeconomic impacts of climate change. These three key global agencies were selected because the issues of food and agriculture, energy security, and climate change are integral to the bioenergy discourse. This is reflected in how each selected institution discusses biomassderived energy, referring not only to its own area of expertise, but expanding the debate beyond its own scope into the spheres of the other two IOs, overlapping their agendas.

The article is structured as follows. In Section 2, I present two distinct analytical perspectives, namely, those of sociotechnical imaginaries and of utopia. In Section 3, I explain how the empirical data were collected and processed. In Section 4, I discuss the analytical findings in three sub-sections: the first examines how advanced bioenergy imaginaries are sharply differentiated from their predecessors, the second examines how the shift from first- to second-generation biofuels is envisioned, and the third scrutinizes the limited nature of the future sociotechnical imaginaries provided by the organizations. Finally, I present the conclusions in Section 5.

\section{Theoretical perspective}

Introduced and developed by Jasanoff and Kim $(2009,2013)$, "sociotechnical imaginaries" is a hybrid term that straddles meaning-making and sense-making processes, linking them by means of socioeconomic structures and technological choices. In their cross-national study of nuclear energy policy in the United States and South Korea, these scholars define the concept as "collectively imagined forms of social life and of social order" reflected in "the design and development of innovative technological projects, goals and strategies" (Jasanoff and Kim, 2009: 120). In other words, sociotechnical imaginaries are powerful visions that serve as both the ends of policy-making and as tools for legitimizing specific technological paths and/or 
shaping social responses to innovation (Jasanoff and Kim, 2013). Furthermore, Jasanoff and Kim (2009) argue that "imaginaries are at once descriptive of attainable futures and prescriptive of the futures that ought to be attained" (p. 120). As such, the concept serves as an interpretative envelope that helps us address how the imaginary of advanced bioenergy technology, together with prescribed futures regarding its shape and role in society, is construed in the deliberations of selected IOs.

Apart from cross-national studies of nuclear power conducted by Jasanoff and Kim (2009, 2013), in recent years, the concept of sociotechnical imaginaries has been applied in research into biofuels. For example, Levidow and Papaioannou (2012) explore current state imaginaries contained in policies promoting bioenergy innovation in the United Kingdom. These scholars identify three major visions through which biomass-derived fuels are promoted in the country: localization of energy production, diversification of agricultural practices, and substitution of oil (Levidow and Papaioannou, 2012). Eaton et al. (2013) study the development of local energy production from wood biomass in Michigan, the United States, claiming that their paper "contributes to theories of imaginaries by showing how key framings of the past also frame future possibilities" (p. 26).

My take on Jasanoff and Kim's (2009, 2013) analytical framework requires two modifications. First, the scholars assume that "sociotechnical imaginaries can be identified, illuminated and critiqued through cross national comparison" (Jasanoff and Kim, 2009: 121). However, I argue that not only national policies but, particularly in our increasingly globalized world, international policy-making and policy-envisioning can also serve as useful sites for examining visionary practices. In this paper, my focus on the formation of sociotechnical imaginaries therefore shifts from the national to global levels. More specifically, I highlight IOs, which not only reflect the desires, goals, and priorities of their state-members but also provide expert- and science-based imaginaries that can influence both 
political leaders and societies at the national level (Barnett and Finnemore, 2004; Jasanoff, 2012). In this sense, global agencies exercise their influence and power in the form of epistemic authority "based on having special knowledge and moral expertise" (Zürn et al., 2012: 86).

Exemplifying this argument, FAO provides policy assistance and information, particularly to developing countries, about improving food production and access. Among many documents issued by the organization, the major flagship publications are yearly scientific and statistical reports entitled The State of Food and Agriculture and The State of Food Insecurity in the World. By providing expertise in the form of assessments, analyses, and statistics, IEA is at the centre of global dialogue on energy production and resources. Its special annual report World Energy Outlook is considered the world's most authoritative analysis of global energy markets, trends in energy demand and supply, and projections of future energy security in relation to economic development and environmental protection. IPCC is known mostly for its assessments of scientific, technical, and socioeconomic information necessary for understanding, mitigating, and adapting to climate change. The Panel's reports play a pivotal epistemic role in intergovernmental negotiations held under the United Nations Framework Convention on Climate Change. IPCC's internationally recognized scientific authority on climate change was particularly strengthened in 2007 when it shared the Nobel Peace Prize with Al Gore.

It is important to note that, despite modifying the analytical approach by shifting its focus from the national to the international level, the theoretical perspective remains a comparative exercise that, with its greater heuristic power, allows the tracing of potential similarities and/or differences in the global bioenergy debate. Transposing Jasanoff and Kim's (2009, 2013) approach to the international arena while assessing the second-generation biofuel imaginary provided by only one IO would result in a much weaker argument. Second, in 
developing their concept of sociotechnical imaginaries, Jasanoff and Kim (2009, 2013) particularly emphasize the capacity and importance of imagination as a "cultural resource" facilitating novel forms of social life by projecting "visions of what is good, desirable, and worth attaining for a political community" (Jasanoff and Kim, 2009: 122-123). These visions of future possibilities are, according to Jasanoff and Kim (2009), so embedded in the social organization and various techno-scientific practices, that "they inform and shape trajectories of research and innovation" (p. 122). Such an understanding, however, raises critical questions as to whose visions of future possibilities these are, for whom they are good and desirable (only for a particular political community?), and why certain policy-makers would find them worth realizing. Moreover, following Alf Hornborg (2014b), it is also legitimate to ask for whom the envisioned technology will be accessible, and at the expense of whose resources and work (p. 91).

This connotes two central and interrelated aspects of contemporary debates on how to reimagine, reconfigure, and transform the socioeconomic structure. On one hand, what is good, desirable, and worth attaining could constitute an ideology for policy-makers in efforts to uphold the status quo, simultaneously obscuring "the real condition of society" (Hedrén, 2014: 58). As such, an ideology would constitute what Jameson (1983) calls a "strategy of containment" that "allows what can be thought to seem internally coherent in its own terms, while repressing the unthinkable ... which lies beyond its boundaries" (pp. 37-38). On the other hand, the imaginary of what is good, desirable, and worth attaining could be understood as utopian thinking "based on interest in transforming a given condition" rather than maintaining it (Hedrén, 2014: 58). Utopia, in this sense, expresses the desire for a better way of living, beyond or outside dominant socioeconomic structures (Bloch, 2000; Bradley and Hedrén, 2014; Harvey, 2000; Levitas, 2007). 
For Jameson (1994, 2004, 2005, 2010) and Levitas (2000, 2003, 2007, 2011), the concept of utopia serves as an analytical category that denotes hope for a radically different and better society (Bradley and Hedrén, 2014). By definition, utopia is always somewhere else - a "noplace" - though it is trapped within the imaginative potentials and resources available in the contemporary socioeconomic system. As Jameson (2005) points out, "even a no-place must be put together out of already existing representations" (p. 24). As such, the function of utopia "lies not in helping us to imagine a better future but rather in demonstrating our utter incapacity to imagine such a future ... so as to reveal the ideological closure of the system in which we are somehow trapped and confined" (Jameson, 2005: 46).

From this perspective, Levitas proposes that utopia is best understood as "a method of considering the future, not the stipulation of a goal [emphasis added]" (Levitas, 2007: 303). In other words, utopia does not offer a blueprint or set of criteria for how to attain a radically "green" transformation. Rather, it is a holistic, reflexive method that "provides a critical tool for exposing the limitations of current policy discourses about economic growth and ecological sustainability" in order to facilitate thinking about possible alternative futures (Levitas, 2013: xi). Similarly, Jameson (2010) points out that in analysing future imaginaries, it is not what can be envisaged or imagined but rather what is unimaginable and inconceivable that should be emphasized. In his view, such an approach would strive to locate radical differences and retrieve signals of otherness. As Jameson (1994) argues, "the ideals of Utopian living involve the imagination in a contradictory project" and not just another repetition of the present (p. 56).

By applying a critical and diagnostic utopian method, I concentrate on three aspects of sociotechnical imaginaries that underpin the debate on second-generation biofuels. First, I focus on the visions the IOs put forward to cast advanced bioenergy as new and innovative. In this way, I strive to locate components of radical differences and retrieve signals of otherness. 
Second, I define the limits beyond which the IOs do not go in their future imaginaries. Third, by determining the boundaries of their conceptualizations, I expose the purpose of envisioning advanced technologies for producing energy from biomass as innovative and whether the purportedly new, better, and greener impulse that could bring radical change is only illusory.

\section{Data collecting and processing}

The empirical data spanning the twenty-four years from 1990 to 2013 were collected and their content extracted in two steps. First, the primary documents, i.e., reports, analyses, assessments, and other papers, were obtained from the online FAO (www.fao.org), IEA (www.iea.org), IEA Bioenergy (www.ieabioenergy.com), and IPCC (www.ipcc.ch) databases using the following search terms: "agrofuel”, "agroenergy", "biofuel”, "bioenergy", "biomass energy", "biomass fuel", "biodiesel”, "biogas", "energy crop", and "ethanol”. Bearing in mind that first- and second-generation bioenergy technologies include various biomass-derived production patterns and are discussed by the selected IOs in various contexts and conceptual arrangements, the primary selection of empirical data was not restricted to any specific type of biofuel; instead, the scope of the search was broadly defined to provide a rich base of documents for the next processing step.

However, since the main focus of this article is not bioenergy in general but two generational modes of biofuel production technologies, particularly the advanced type, the preselected data were submitted to secondary scanning and analysis to narrow the range of documents and extract fragments of texts that specifically discuss first- and second-generation biomass-derived energy. The secondary selection was based on the following search terms: “advanced”, “algae”, “cellulose”, “conventional”, “1st generation”, “2nd generation”, "first generation", "next generation", and "second generation". The texts selected in the second step were subjected to comparative analysis, which revealed characteristic patterns in how the 
three IOs construct, discuss, imagine, envision, and promote the second-generation bioenergy concept. Based on these observations, the empirical data were organized into specific points of reference that serve as the basis for the analytical section.

\section{Analysis}

The analytical section begins by examining how advanced biofuels are differentiated from conventional ones in IO deliberations. In doing so, the analysis exposes how the objective of shifting from first- to second-generation biofuels is envisioned and justified in the imaginaries expressed by the selected institutions. Finally, the analysis scrutinizes whether the technological innovation involved in pursuing this potential transition displays traces of utopian impulse or instead constitutes ideological closure.

\subsection{Identity through difference}

In discussions pursued by the three selected IOs, the envisioned identity of second-generation bioenergy is based primarily on juxtaposing it as a better alternative in sharp contrast to firstgeneration biofuels depicted in negative terms. This differentiation, which imagines cellulosebased technology in a positive light vis-à-vis harmful and inefficient conventional biomassderived energy production, designates the second-generation type as superior to its predecessor in two striking ways.

The first way to construct this difference-based imaginary identity is to emphasize the greater ability of second-generation biofuels to substantially lower greenhouse gas (GHG) emissions. Numerous documents issued by the IOs anticipate that, unlike conventional biofuels, cellulose-based energy could have much greater potential to dramatically reduce lifecycle GHG emissions (Cohen et al., 2008; FAO, 2008c,d,e,g, 2009a,b; FAO/GBEP, 2007; IEA, 2001, 2002, 2003a,b, 2004a,b,c, 2008a,b,c, 2010; IEA Bioenergy, 2006, 2009; IPCC, 
2007a,b,c,d, 2012; Mabee and Saddler, 2006). For example, according to the FAO Committee on Commodity Problems, reporting from its sixty-seventh session, "compared to current generation biofuels, cellulosic ethanol is far more advantageous from a GHG point of view, because it is nearly carbon neutral" (FAO, 2009b: 8). In a paper on bioenergy development, FAO estimates that "second-generation biofuels, including cellulosic bioethanol, are expected to produce significant GHG savings - possibly up to 80 percent" (FAO/GBEP, 2007: 38). Similarly, IEA envisages that second-generation biofuels are expected to be superior to conventional technology in this regard (IEA, 2008b: 33). The agency notes that "the largest difference between the $1^{\text {st }}$ and $2^{\text {nd }}$ generation fuels is likely to be the GHG emission performance" (IEA Bioenergy, 2006: 58), particularly when the net GHG reduction achieved using advanced bioenergy technologies "can be even greater than 100\%" (IEA, 2004a: 61). IPCC recognizes that cellulose-based biofuels may provide larger GHG emission reductions than can conventional biomass fuels (IPCC, 2007a: 343). The Panel promotes advanced production patterns as a "key mitigation technology and practice projected to be commercialized before 2030" (IPCC, 2007b: 60; 2007c: 10; 2007d: 17).

The second way to depict the imaginary of advanced bioenergy as different from and better than conventional options results in an even stronger contrast, because it is based on the controversy surrounding the alleged role of the first-generation production path in negatively influencing global agricultural commodity prices and food security. The comparative argumentation supporting advanced bioenergy refers to two aspects of the food-versus-fuel conflict.

On one hand, the IOs explicitly maintain that, compared with conventional biofuels derived from food and feed crops, the cellulosic option could allow the production of advanced bioenergy from a significantly wider variety of feedstocks, providing a much more efficient processing pattern (FAO, 2007, 2008e; FAO/GBEP, 2007; FAO/IIED, 2008; IEA, 
2004a, 2006; IEA Bioenergy, 2006). Accordingly, the widespread and more productive use of non-food/feed biomass would significantly increase the potential of second-generation biofuels without the need to reduce the production of food and feed crops. Advanced bioenergy could arguably help alleviate food-versus-fuel competition and improve food security in general (FAO, 2007, 2008a,b,c,g; FAO/GBEP, 2007; Flammini, 2008; IEA, 2004a, 2006, 2008b, 2010; IEA Bioenergy, 2009). To exemplify, according to the FAO report from its 2008 high-level conference on world food security, "the commercialization of secondgeneration biofuels that do not utilize food crops or compete for resources could reduce the pressure on commodity markets" (FAO, 2008a: 4) and "the higher technological conversion efficiency of second-generation technologies could contribute to reducing feedstock requirements" (FAO, 2008a: 3). Another FAO analysis asserts that second-generation biofuel technologies "are expected to circumvent the food-fuel debate" (Flammini, 2008: 8). Similarly, IEA assumes that "moving from conventional grain and sugar crops to cellulosic biomass for the production of biofuels opens the door to a much greater variety of potential feedstock sources" (IEA, 2004a: 133) In assessing liquid biofuels from biomass, the Agency contends that "with most $2^{\text {nd }}$ generation biofuels the ability to process lingocellulosic feedstocks is a primary advantage of this $2^{\text {nd }}$ generation pathway. These feedstocks are abundant, geographically diverse, generally lower cost than starch or sugar feedstocks, and significant quantities are produced today that are currently wasted” (IEA Bioenergy, 2006: 6).

On the other hand, second-generation biofuels are envisaged as biomass energy processed from feedstocks that could be grown on marginal, abandoned, degraded, or other low-quality land. Several documents from the organizations argue that advanced bioenergy feedstocks require minimal or no acreage in addition to that already used to grow food or feed and, unlike first-generation biofuels, could alleviate land competition with other agricultural outputs (FAO, 2007, 2008a,b,g; FAO/GBEP, 2007; IEA, 2004a, 2006, 2008b, 2010; IEA 
Bioenergy, 2008; IPCC, 2007a). For example, FAO states that "with the second-generation technologies, a significant share of the additional biomass needed is assumed to come from regenerated and marginal land not currently used for arable crops and pasture, as well as agricultural and forestry residues and organic waste" (FAO, 2008a: 3). In its World Energy Outlook 2006, IEA contends that various types of cellulosic feedstocks "could be grown on poorer quality soils than those currently used to grow crops for conventional ethanol production, requiring less fertilizer and water" (IEA, 2006: 409). According to the Agency, "second-generation biofuels offer the prospect, with feedstocks produced on idle or marginal lands, to avoid the need to bring significant amounts of new land into agricultural production" (IEA, 2008b: 31). In the same report, the organization concludes that while "less good" firstgeneration biofuels are strongly criticized with regard to their "competition for food crop feedstock, pushing up food commodity prices $\ldots$ a lot of hope has been placed on $2^{\text {nd }}-$ generation biofuels. Where these rely on crops and forest residues, or high-yielding, non-food energy crops grown specifically for feedstocks, they are considered to be produced more sustainably, with better land use opportunities, including potential production on marginal lands" (IEA Bioenergy, 2008: 99). As IPCC puts it in the Fourth Assessment Report, "the conversion of ligno-cellulosic sources into biofuels is the most attractive biomass option ... Cellulosic crops are attractive because they have much higher yields per hectare than sugar and starch crops, they may be grown in the areas unsuitable for grains and other food/feed crops and thus do not compete with food" (IPCC, 2007a: 342).

As can be observed, this conceptual juxtaposition of conventional versus advanced bioenergy produces specific effects in the form of a strong contrast differentiating the two production patterns and particularly facilitating the role of second-generation biofuels. This casts the currently predominant technology in a negative light, attempting to eliminate firstgeneration biofuels as a future option. Instead, the future is populated by the imaginary of a 
novel and presumably more efficient energy technology that, unlike its predecessor, might meet the requirements of radical socioeconomic transition. So far, the second-generation bioenergy imaginary carries the promise of greater potential to dramatically reduce GHG emissions, a wider variety of exploitable feedstocks, as well as more efficient land use and thus no conflict with food or feed production patterns. Do these positive attributes signal a utopian impulse for radical change?

\subsection{Illusory change}

The imaginary efforts to sharply contrast and differentiate advanced biofuel technology from its predecessor suggest that the political intention is to shift from the inefficient and controversial first-generation to a much more effective and simultaneously less-contested second-generation bioenergy option, as soon as it is available for policy-makers to implement. Despite clear indications that specific innovative ways of processing biomass could provide a better way to reduce GHG emissions while not competing over agricultural land and food crop cultivation, the desire to shift to a new production pattern is expressed very briefly (FAO, 2008f; IEA, 2006, 2007, 2008b). Instead, closer examination indicates that the new technology "waiting around the corner" is perceived not so much as progress towards an alternative system that could radically change production patterns, in particular, alleviating the negative impacts of the previous technology, but as an upgrade and replication of the previous regime aimed at perpetuating both options and thus facilitating the biofuel industry in general (FAO, 2008d,e,f,g, 2009b; FAO/GBEP, 2007; IEA, 2006, 2008a,b, 2010; IEA Bioenergy, 2005, 2006, 2009; IPCC, 2007a, 2012; Walter et al., 2007).

While FAO characterizes cellulosic biofuel as a "forerunner", alluding to the emergence of a new technology (FAO/GBEP, 2007: 14), it states that "research and development on second-generation technologies, in particular, could significantly enhance the future role of 
biofuels" (FAO, 2008g: 9). This suggests that technological developments play a supplementary rather than substitutionary role in the case of biofuels. Moreover, according to the FAO report, The State of Food and Agriculture 2008, "technological innovation including the development of second-generation biofuels based on cellulosic feedstocks may expand the potential and the range of countries where biofuels could make a significant contribution to energy security. However, it is not clear when second-generation technologies may become commercially viable. When they do, first- and second-generation fuels are likely to continue to coexist" (FAO, 2008g: 88). The assumption about the coexistence of both technological paths was also promoted in 2009 by the FAO Committee on Commodity Problems at its sixty-seventh session: "from an analytical and projections perspective, international organizations should consider both first- and second-generation biofuels in their assessments of energy futures" (FAO, 2009b: 8).

The inevitability that advanced biofuel technologies would not replace conventional biofuel production and the push for both patterns to coexist is also reflected in documents issued by IEA. According to the Agency, "it is expected that, at least in the near to mediumterm, the biofuel industry will grow only at a steady rate and encompass both $1^{\text {st }}-$ and $2^{\text {nd }}-$ generation technologies that meet agreed environmental, sustainability and economic policy goals" (IEA, 2008b: 7). Furthermore, the Agency also suggests that "the transition to an integrated $1^{\text {st }}$ - and $2^{\text {nd }}$-generation biofuel landscape is therefore most likely to encompass the next one to two decades, as the infrastructure and experiences gained from deploying and using $1^{\text {st }}$-generation biofuels is transferred to support and guide $2^{\text {nd }}$-generation biofuel development" (IEA, 2008b: 7). Another report, prepared by IEA Bioenergy, bluntly states that "while the development of the 2nd generation biofuel technology is important, these processes are not likely to replace the 1 st generation biofuels for many years, if ever", so "the use of $2^{\text {nd }}$ 
generation biofuels needs to be viewed as a means to augment and not to replace the use of $1^{\text {st }}$ generation biofuels" (IEA Bioenergy, 2006: v-vi).

Like FAO and IEA, in its 2007 Fourth Assessment Report, IPCC concludes that "the global potential for biofuels will depend on the success of technologies to utilize cellulose biomass" (IPCC, 2007a: 326). The Panel also envisages that the use of both current and advanced biomass-derived fuels would offer additional $\mathrm{CO}_{2}$ reduction potential (IPCC, 2007a: 326). Moreover, in its Special Report on Renewable Energy Source and Climate Change Mitigation, IPCC (2012) projects that "in the near to medium term, the biofuel industry, encompassing first- and second-generation technologies ... will grow at a steady rate" (p. 285).

The desire to base advanced bioenergy technology on conventional biofuel production patterns, and even to continue supporting both options in the future to strengthen the biofuel market in general, lacks utopian drive and is an obvious example of the inability to escape the trap of contemporary socioeconomic conditions. Instead, it expresses the ideological strategy of containment that, in Jameson's words, allows only for the imaginary internally coherent with the currently dominant socioeconomic system, while excluding the unthinkable (Jameson, 1983).

\subsection{The cost imperative}

What, then, is the role of sociotechnical imaginaries of second-generation biofuels, which are directed towards developing more sophisticated and beneficial technology if, in fact, the actual desire is to keep both options - a flawed and inefficient predecessor together with its successor characterized as better functioning, much more efficient, and less problematic - in coexistence? Looking more closely at the institutional debate, the attractiveness of secondgeneration bioenergy lies not just in its presumable superiority at reducing GHG emissions or 
its potential to alleviate land and food security concerns, but more specifically in the low cost of its feedstocks. As indicated in the first part of the analysis, this is because developing technologies to accommodate a wider range of cellulose-based resources provides abundant access to cheap biomass and types of land for cultivation globally. However, the crucial problem with advanced bioenergy is that the technological processes necessary to convert its cheap biomass feedstocks into energy are still costly, making it impossible for secondgeneration biofuels to successfully compete on the market against other fuels (Cohen et al., 2008; FAO, 2008b; FAO/GBEP, 2007; FAO/IIED, 2008; IEA, 2004a, 2006, 2010, 2011a,b; IEA Bioenergy, 2006, 2009; IPCC, 2012; Mabee and Saddler, 2006).

IEA observes that "if cellulose-ethanol processes can meet cost targets, a far higher percentage of petroleum transport fuels could cost-effectively be replaced with biofuels. Ultimately, advanced biomass-to-liquids processes might provide the most efficient (and therefore least land-intensive) approach to producing biofuels, but costs will need to come down substantially for this to occur" (IEA, 2004a: 23). The Agency further maintains that advanced biofuels "could become very attractive options for future transport fuel, given their high conversion efficiencies and very low well-to-wheels greenhouse gas emissions" but only "if costs can be reduced to acceptable levels" (IEA, 2004a: 83). Hence, IEA Bioenergy concludes that, paradoxically, "the ability to process less costly inputs does come at a cost [emphasis added], and all of the $2^{\text {nd }}$-generation systems have much higher capital costs than the $1^{\text {st }}$-generation biofuels" (IEA Bioenergy, 2006: 34). FAO points out that "the feedstocks of second-generation biofuels are low-cost - but the manufacturing processes require sophisticated technologies, largely still under development" (FAO, 2008b: 7).

The key role of innovation and technological development in sociotechnical imaginaries of second-generation biofuels is not to design radically alternative or novel conversion and production processes, but specifically to reduce the cost barrier and prepare advanced 
bioenergy technologies for expected commercialization. In other words, any "new" conversion technologies that could make necessary production processes more efficient and less problematic would epitomize the promise of future price reductions. It is a type of innovation that aims strictly to advance the optimization of particular technologies in order to reduce their price in the first place (FAO, 2008e,g; FAO/GBEP, 2007; IEA, 2001, 2003a,b, 2004a, 2006, 2008a,b,c, 2010, 2011a,b; IEA Bioenergy, 2004; IPCC, 2001, 2007a, 2012; OECD/IEA, 2007).

To exemplify, in its report on liquid biofuels from biomass, IEA maintains that "part of the higher cost is fundamentally inherent in the more extensive process required for the $2^{\text {nd }}-$ generation fuels, but part of the high cost is a function of the state of development of the new technologies and the lack of learning experience with the new fuels" (IEA Bioenergy, 2006: 35). According to the Agency, "successful implementation of the advanced technologies is expected to lead to significant reductions in the cost of producing ethanol" (IEA Bioenergy, 2004: 9). When discussing future energy developments in its World Energy Outlook 2006, IEA envisages that "in neither scenario are second-generation biofuels, such as lingocellulosic ethanol or biomass gasification, assumed to penetrate the market. This is because important breakthroughs in developing these technologies will be necessary before they can be deployed commercially on a large scale. It is nonetheless possible that such breakthroughs could occur in the near future, which could pave the way for faster development of biofuels markets" (IEA, 2006: 395).

According to FAO`s 2008 report on forests and energy, "in the medium-term, it is expected that technology will become available for an economically competitive production of liquid biofuels from cellulosic material" (FAO, 2008e: 2). In line with IEA reasoning, FAO affirms that "reduced competition with food production, an increase in energy efficiency and improved overall energy balance" could be attained only "if technological developments 
make it more efficient and at least as economical to produce liquid biofuels from cellulosic material rather than from food crops" (FAO, 2008e: 32-33). In the same report, FAO concludes that "technologies may soon be available to convert cellulose to liquid biofuels on a large-scale at economically attractive prices" (p. 45). Finally, discussing current agronomic and conversion technologies in The State of Food and Agriculture 2008, FAO assumes that "technological innovation in biofuel processing could also lower costs dramatically, potentially bringing second-generation biofuels derived from cellulosic feedstocks into commercial production, thereby reducing competition with agricultural crops and the pressure on commodity prices" (FAO, 2008g: 6).

Similarly, as IPCC expresses in its Third Assessment Report, "improvements in biofuel conversion routes, such as the enzymatic hydrolysis of ligno-cellulosic material to ethanol, may help narrow the cost disadvantage versus fossil fuels" (IPCC, 2001: 173). The Panel also observes that "the penetration of second-generation biofuels depends on the speed of technological development and the market penetration of gasification technology for synfuels and hydrolysis technology for the production of ethanol from woody biomass" (IPCC, 2007a: $629)$.

As can be observed, the sociotechnical imaginaries of second-generation biofuels expressed by the IOs are necessarily aligned and conflated with the requirement of costeffectiveness in order to be competitive on the energy market. In line with Hornborg (2014b), it can be concluded that the imaginary of advanced bioenergy technology serves as "a crystallization or mediator of extant market relationships" (p. 93).

\section{Conclusions}

At first glance, the sociotechnical imaginaries of second-generation biofuels provided by selected international organizations promise a better, greener future. In sharp contrast to its 
conventional predecessor, advanced bioenergy technology is envisaged as radically reducing GHG emissions, being more efficient and productive, and not competing with other agricultural outputs. Closer examination, however, reveals that something more is at stake than just this delusive utopian impulse. The development and implementation of the technologically advanced production of biomass-derived energy do not manifest innovation and progress in the interest of radical change, but rather the complete opposite. This is because the desire for systemic closure that requires taking the cost-effective path and implementing only illusory alterations within established socioeconomic limits represses any manifestations of the new and innovative that could exert influence beyond their boundaries. Consequently, the imaginaries of potential technological progress and advances "waiting around the corner" of second-generation bioenergy signify an ideological stranglehold, as they reflect the necessity of enhancing and commercializing it at the lowest cost possible. This powerful strategy aims to project the illusion of radical change while concealing that the envisioned technological developments strive to maintain the status quo rather than altering it to achieve a better and greener future. In this sense, the sociotechnical imaginaries of advanced biofuels provided through the epistemic authority of international organizations are devoid of utopian potential. Sweet dreams are made of cellulose but they have their high price.

Although the analysis exposes a particular trend in how three major IOs provide their expert- and science-based imaginaries of second-generation bioenergy, the findings of this paper offer a glimpse into a pattern of actual decision-making, namely, that in contemporary industrial capitalist societies, the main ambition of policy-makers is to maintain and stabilize the dominant system - which is currently being challenged, particularly by the future escalation of energy insecurity, agricultural stagnation, and climate change - rather than striving for radically alternative arrangements. However, reducing the negative side effects of 
the established economy is not the same as developing a new socioeconomic system based on radically alternative principles. As such, there is a need for more research into the possibilities and limitations of the dominant economic structure, and for critical evaluation of the fundamental changes necessary in order to address the environmental and societal challenges we face today. Shedding light on a multitude of experimental movements, micro-practices, and concepts - including various strategies of de-growth (Buch-Hansen, 2014; Sekulova et al., 2013) or various manifestations of peer-to-peer and solidarity economies (Bauhardt, 2014; Bradley and Hedrén, 2014) - is a way to reveal important utopian impulses, not only for experts and researchers but particularly for policy-makers.

\section{REFERENCES}

Barnett, M., Finnemore, M. (2004). Rules for the World: International Organizations in Global Politics. Ithaca and London: Cornell University Press.

Bauhardt, H. (2014). Solutions to the crisis? The Green New Deal, degrowth, and the solidarity economy: alternatives to the capitalist growth economy from an ecofeminist economics perspective. Ecological Economics, 102, 60-68.

Bernton, H., Kovarik, W., Sklar, S. (2010). The Forbidden Fuel: A History of Power Alcohol. Lincoln and London: University of Nebraska Press.

Bloch, E. (2000). The spirit of utopia. Stanford, CA: Stanford University Press.

Bradley, K., Hedrén, J. (2014). Utopian Thought in the making of Green Futures. In: K. Bradley, J. Hedrén (Eds.), Green Utopianism: Perspectives, Politics and Micro-Practices (pp. 1-20). New York and London: Routledge. 
Buch-Hansen, H. (2014). Capitalist diversity and de-growth trajectories to steady-state economies. Ecological Economics, 106, 167-173.

Cohen, M.J., Tirado, C., Aberman, N.-L., Thompson, B. (2008). Impact of Climate Change and Bioenergy on Nutrition. Rome: IFPRI and FAO.

Bradshaw, M.J. (2013). Global Energy Dilemmas: Energy Security, Globalization and Climate Change. Cambridge: Polity Press.

Eaton W.E., Gasteyer, S.P., Busch, L. (2013). Bioenergy Futures: Framing Sociotechnical Imaginaries in Local Places. Rural Sociology, first published online. Available at: http://dx.doi.org/10.1111/ruso.12027

FAO (2007). Assessment of the World Food Security Situation. Committee on World Food Security, Thirty-third Session, CFS:2007/2. Rome: FAO.

FAO (2008a). Bioenergy, Food Security and Sustainability - Towards an International Framework. High-Level Conference on Food Security: The Challenges of Climate Change and Bioenergy, Rome, 3-5 June 2008, HLC/08/INF/3. Rome: FAO.

FAO (2008b). Bioenergy and Land Tenure: The Implications of Biofuels for Land Tenure and Land Policy. Rome: FAO. 
FAO (2008c). Bioenergy Policy, Markets and Trade and Food Policy. Technical Background Document from the Expert Consultation, Rome, 18-20 February 2008. Rome: FAO.

FAO (2008d). Climate Change, Bioenergy and Food Security: Options for Decision Makers Identified by Expert Meetings. High-Level Conference on Food Security: The Challenges of Climate Change and Bioenergy. Rome, 3-5 June 2008, HLC/08/INF/5. Rome: FAO.

FAO (2008e). Forests and Energy: Key Issues, FAO Forestry Paper, 154. Rome: FAO.

FAO (2008f). Soaring Food Prices: Facts, Perspectives, Impacts and Actions Required.

High-Level Conference on Food Security: The Challenges of Climate Change and Bioenergy, Rome, 3-5 June 2008, HLC/08/INF/1. Rome: FAO.

FAO (2008g). The State of Food and Agriculture 2008. Biofuels: Prospects, Risks and Opportunities. Rome: FAO.

FAO (2009a). Round Table on the Bioenergy Rush: Opportunities and Risks for Food Security, the Environment and Rural Development. Twenty-Ninth Regional Conference for Asia and the Pacific, Bangkok, Thailand, 26-31 March 2009, APRC/08/7. Rome: FAO.

FAO (2009b). The Market and Food Security Implications of the Development of Biofuel Production. Committee on Commodity Problems, Rome, 20-22 April 2009, CCP 09/6. Rome: FAO.

FAO/GBEP (2007). A Review of the Current State of Bioenergy Development in $68+5$ Countries. Rome: FAO. 
FAO/IIED (2008). Fuelling Exclusion? The Biofuels Boom and Poor People's Access to Land. London: FAO/IIED.

Flammini, A. (2008). Biofuels and the Underlying Causes of High Food Prices. Rome: FAO.

Harvey, D. (2000). Spaces of Hope. Berkeley, CA: University of California Press.

Hedrén, J. (2014). Utopianism in Science: The Case of Resilience Theory. In: K. Bradley, J. Hedrén (Eds.), Green Utopianism: Perspectives, Politics and Micro-Practices (pp. 57-75). New York and London: Routledge.

Hornborg, A. (2014a). Ecological economics, Marxism, and technological progress: Some explorations of the conceptual foundations of theories of ecologically unequal exchange. Ecological Economics, 105, 11-18.

Hornborg, A. (2014b). Why Solar Panels Don’t Grow on Trees. In: K. Bradley, J. Hedrén (Eds.), Green Utopianism: Perspectives, Politics and Micro-Practices (pp. 76-97). New York and London: Routledge.

IEA (2001). Saving Oil and Reducing $\mathrm{CO}_{2}$ Emissions in Transport: Options and Strategies. Paris: IEA.

IEA (2002). Transportation Projections in OECD: Detailed Report. Paris: IEA. 
IEA (2003a). Integrating Energy and Environmental Goals: Investment Needs and Technology Options. Paris: IEA.

IEA (2003b). Transport Technologies and Policies for Energy Security and $\mathrm{CO}_{2}$ Reductions. Paris: IEA.

IEA (2004a). Biofuels for Transport: An International Perspective. Paris: IEA.

IEA (2004b). Reducing Oil Consumption in Transport: Combining Three Approaches. Fulton L., Office of Energy Efficiency, Technology and R\&D International Energy Agency, IEA/EET Working Paper, EET/2004/01. Paris: IEA.

IEA (2004c). World Energy Outlook 2004. Paris: OECD/IEA.

IEA (2006). World Energy Outlook 2006. Paris: OECD/IEA.

IEA (2007). World Energy Outlook 2007. Paris: OECD/IEA.

IEA (2008a). Energy Technology Perspectives 2008: In Support of the G8 Plan for Action. Scenarios \& Strategies to 2050. Paris: OECD/IEA.

IEA (2008b). From 1st- to 2nd-generation Biofuel Technologies: An Overview of Current Industry and R\&D Activities. Paris: OECD/IEA.

IEA (2008c). World Energy Outlook 2008. Paris: OECD/IEA. 
IEA (2010). Sustainable production of second-generation biofuels: Potential and perspectives in major economies and developing countries. Paris: IEA.

IEA (2011a). Technology Roadmap: Biofuels for Transport. Paris: IEA.

IEA (2011b). Technology Roadmap: Bioenergy for Heat and Power. Paris: IEA.

IEA (2011c). World Energy Outlook 2011. Paris: OECD/IEA.

IEA Bioenergy (2004). Biofuels for Transport. T39: 2004:01. Paris: IEA Bioenergy.

IEA Bioenergy (2005). Ethanol from Lignocellulosic: Policy options to support bioethanol production. Canada: IEA Bioenergy Task 39.

IEA Bioenergy (2006). Second Generation Biofuels: A Review from a Market Barrier Perspective. Canada: IEA Bioenergy Task 39.

IEA Bioenergy (2008). Gaps in the Research of $2^{\text {nd }}$ Generation Transportation Biofuels. T41(2): 2008:1. Paris: IEA Bioenergy.

IEA Bioenergy (2009). 2nd generation Biofuels and Trade: An Exploratory Study. IEA Bioenergy Task 40. Paris: IEA.

IPCC (2001). Climate Change 2001: Mitigation. In: B. Metz, O. Davidson, R., Swart \& J. Pan 
(Eds.), A Contribution of Working Group III to the Third Assessment Report of the Intergovernmental Panel on Climate Change. Cambridge: Cambridge University Press.

IPCC (2007a). Climate Change 2007: Mitigation. In: B., Metz, O.R. Davidson, P.R., Bosch, R. Dave \& L.A. Meyer (Eds.), Contribution of Working Group III to the Fourth Assessment Report of the Intergovernmental Panel on Climate Change. Cambridge: Cambridge University Press.

IPCC (2007b). Climate Change 2007: Synthesis Report. In: Core Writing Team, R.K. Pachauri, \& A. Reisinger (Eds.), Contribution of Working Groups I, II and III to the Fourth Assessment Report of the Intergovernmental Panel on Climate Change. Cambridge: Cambridge University Press.

IPCC (2007c). Summary for Policy Makers. In: Climate Change 2007: Mitigation. B. Metz, O.R., Davidson, P.R., Bosch, R., Dave, L.A., Meyer (Eds.), Contribution of Working Group III to the Fourth Assessment Report of the Intergovernmental Panel on Climate Change. Cambridge: Cambridge University Press.

IPCC (2007d). Summary for Policy Makers. In: Climate Change 2007: Synthesis Report.

Core Writing Team, R.K., Pachauri, A. Reisinger (Eds.), Contribution of Working Groups I, II and III to the Fourth Assessment Report of the Intergovernmental Panel on Climate Change. Cambridge: Cambridge University Press.

IPCC (2012). Renewable Energy Sources and Climate Change Mitigation: Special Report of the Intergovernmental Panel on Climate Change. Technical Support Unit Working Group III 
and Potsdam Institute for Climate Impact Research (PIK). Cambridge: Cambridge University Press.

IPCC (2014). Climate Change 2014: Mitigation of Climate Change. Chapter 8: Transport. Working Group III Contribution to the IPCC 5th Assessment Report, Final Draft. Available at: http://report.mitigation2014.org/drafts/final-draft-postplenary/ipcc_wg3 ar5 finaldraft postplenary chapter8.pdf

Jameson, F. (1983). The Political Unconscious: Narrative as a Socially Symbolic Act. London: Routledge.

Jameson, F. (1994). The Seeds of Time. New York, NY: Columbia University Press.

Jameson, F. (2004). The Politics of Utopia. New Left Review, 25, 35-54.

Jameson, F. (2005). Archaeologies of the Future: The desire called utopia and other science fictions. London: London.

Jameson, F. (2010). Utopia as Method, or the Uses of the Future. In: Gordin, M.D., Tilley, H., Prakash, G. (Eds.), Utopia/Dystopia: Conditions of Historical Responsibility (pp. 21-44). Princeton and Oxford: Princeton University Press.

Jasanoff, S. (2012). Science and Public Reason. New York: Routledge. 
Jasanoff, S., Kim, S.-H. (2009). Containing the Atom: Sociotechnical Imaginaries and Nuclear Power in the United States and South Korea. Minverva, 47, 119-146.

Jasanoff, S., Kim, S.-H. (2013). Sociotechnical Imaginaries and National Energy Policies. Science as Culture, 22(2), 189-196.

Kuchler, M. (2010). Unravelling the argument for bioenergy production in developing countries: A world-economy perspective. Ecological Economics, 69(6), 1336-1343.

Kuchler, M., Linnér, B-O. (2012). Challenging the food vs. fuel dilemma: genealogical analysis of the biofuel discourse pursued by international organizations. Food Policy, 37(5), $581-588$.

Levidow, L., Papaioannou, T. (2013). State imaginaries of the public good: shaping UK innovation priorities for bioenergy. Environmental Science and Policy, 30, 36-49.

Levitas, R. (2000). For Utopia: The (limits of the) Utopian function in late capitalist society. Critical Review of International Social and Political Philosophy, 3(2-3), 25-43.

Levitas, R. (2003). Introduction: The Elusive Idea of Utopia. History of the Human Sciences. $16(1), 1-10$.

Levitas, R. (2007). Looking for the blue: The necessity of utopia. Journal of Political Ideologies. 12(3), 289-306. 
Levitas, R. (2011). The Imaginary Reconstitution of Society: Utopia as Method. In: Baccolini, R., Moylan, T. (Eds.), Utopia Method Vision: The Use Value of Social Dreaming (3rd Ed., pp. 47-68). Bern, Switzerland: Peter Lang AG.

Levitas, R. (2013). Utopia as Method: The Imaginary Reconstitution of Society. Basingstoke: Palgrave Macmillan.

Mabee, W.E., Saddler, J.N. (2006). Ethanol from lignocellulosics: Comparing biofuel technology options. IEA Bioenergy Task 39. Paris: IEA.

Matondi, P.B., Havnevik, K., Beyene, A. (Eds.) (2011). Biofuels, Land Grabbing and Food Security in Africa. London and New York: Zed Books.

OECD/IEA (2007). Bioenergy Project Development \& Biomass Supply. Paris: IEA.

Pimentel, D. (Ed.) (2012). Global Economic and Environmental Aspects of Biofuels. Boca Raton, FL: Taylor \& Francis Group.

Popp, A., Krause, M., Dietrich, J.P, Lotze-Campen, H., Leimbach, M., Beringer, T., Bauer, N. (2012). Additional CO2 emissions from land use change — Forest conservation as a precondition for sustainable production of second generation bioenergy. Ecological Economics, 74, 64-70.

Runge, C.F., Senauer, B. (2007). How Biofuels Could Starve the Poor. Foreign Affairs, 86(3), $41-53$. 
Sekulova, F., Kallis, G., Rodríguez-Labajos, B., Schneider, F. (2013). Degrowth: from theory to practice. Journal of Cleaner Production, 38, 1-6.

Smith, J. (2010). Biofuels and the globalization of risk: The biggest change in North-South relationships since colonialism? London and New York: Zed Books.

Walter, A., Rosillo-Calle, F., Dolzan, P.B., Piacente, E., Borges da Cunha, K. (2007). Market Evaluation: Fuel Ethanol. Task 40 Sustainable Bio-energy Trade; Securing Supply and Demand. Brazil and UK: IEA Bioenergy and UNICAMP.

Worldwatch Institute (2007). Biofuels for Transport: global potential and implications for sustainable energy and agriculture. London \& Sterling: Earthscan.

Zürn, M., Binder, M., Ecker-Ehrhardt, M. (2012). International authority and its politicization. International Theory, 4(1), 69-106. 